2012

\title{
Numeracy, Financial Literacy, and Financial Decision-Making
}

Annamaria Lusardi

George Washington University, alusardi@gwu.edu

Follow this and additional works at: https://digitalcommons.usf.edu/numeracy

Part of the Mathematics Commons, and the Science and Mathematics Education Commons

\section{Recommended Citation}

Lusardi, Annamaria. "Numeracy, Financial Literacy, and Financial Decision-Making." Numeracy 5, Iss. 1 (2012): Article 2. DOI: http://dx.doi.org/10.5038/1936-4660.5.1.2 


\title{
Numeracy, Financial Literacy, and Financial Decision-Making
}

\begin{abstract}
Financial decisions, be they related to asset building or debt management, require the capacity to do calculations, including some complex ones. But how numerate are individuals, in particular when it comes to calculations related to financial decisions? Studies and surveys implemented in both the United States and in other countries that are described in this paper show the level of numeracy among the population to be very low. Moreover, lack of numeracy is not only widespread but is particularly severe among some demographic groups, such as women, the elderly, and those with low educational attainment. This has potential consequences for individuals and for society as a whole because numeracy is found to be linked to many financial decisions. As we shift responsibility from governments and employers onto individuals, it is increasingly important to find ways to equip people with the skills that are necessary to make savvy financial decisions.
\end{abstract}

\section{Keywords}

quantitative literacy, financial literacy, numeracy, consumer

Creative Commons License

(c) (i) (8)

This work is licensed under a Creative Commons Attribution-Noncommercial 4.0 License

\section{Cover Page Footnote}

Annamaria Lusardi is the Denit Trust Professor of Economics and Accountancy at the George Washington University School of Business. Previously, she was the Joel Z. and Susan Hyatt Professor of Economics at Dartmouth College, where she taught for nearly twenty years. She has also taught at Princeton University, the University of Chicago Public Policy School, the University of Chicago Booth School of Business, and Columbia Business School. In 2008 she was a visiting scholar at Harvard Business School. Moreover, she is the Director of the Financial Literacy Center, a joint Center of Dartmouth College, the Rand Corporation, and the Wharton School created with the support of the Social Security Administration. She is the recipient of the Fidelity Pyramid Prize, awarded to authors of published applied research that best helps address the goal of improving lifelong financial well-being for Americans.

This article is available in Numeracy: https://digitalcommons.usf.edu/numeracy/vol5/iss1/art2 


\section{Introduction ${ }^{1}$}

In the last few decades, financial markets around the world have become increasingly accessible to the "small investor" as new products and financial services have come on the market. Nonetheless, many of these products are complex and difficult to grasp, especially for financially unsophisticated investors. At the same time, changes in the pension landscape are encouraging increased reliance on the individual, particularly in the United States. Prior to the 1980s, many Americans relied mainly on Social Security and employer-sponsored defined benefit (DB) pension plans. Today, by contrast, Baby Boomers are increasingly turning to defined contribution (DC) plans and Individual Retirement Accounts (IRAs) to help finance their retirement years. Indeed, in 1980, about 40 percent of private-sector pension contributions went to DC plans; 20 years later, almost 90 percent of such contributions went to personal accounts, mostly 401(k) plans (Poterba, Venti, and Wise 2008). The transition to the DC retirement saving model has the advantage of permitting more worker flexibility and labor mobility than in the past, yet it also imposes on employees a greater responsibility to save, invest, and decumulate retirement wealth sensibly. Furthermore, the spread of DC plans means that workers today are directly and immediately exposed to financial market risks, a reality that was less evident in the old DB system. And, as many DB plans have been frozen or terminated, the individually managed accounts will increasingly become the mainstay of retirement. For this reason, individuals will increasingly be called to "roll their own" retirement saving and decumulation plans, and their retirement security will depend ever more on their own decisions and behavior.

How people borrow money and manage their liabilities has also undergone major change of late. Prior to the current financial crisis, consumer credit had expanded rapidly, as had mortgage borrowing. And consumers who borrowed via credit cards or subprime mortgages are in the historically unusual position of having been put in charge of deciding how much they can afford to borrow. Alternative financial services such as payday lending have also become widespread; more than one in five Americans had used a high-cost method of borrowing (including payday loans, pawn shops, auto title loans, tax refund loans, and rent-to-own shops) in the five years prior to the administering of the U.S. 2009 Financial Capability Study. ${ }^{2}$

\footnotetext{
${ }^{1}$ I would like to thank Dorothy Wallace for encouraging me to write this paper and Audrey Brown for excellent research assistance. The work reviewed in the article is in many instances from the articles I have written with several co-authors and I would like to thank them for their support .

${ }^{2}$ See Lusardi (2011).
} 
Financial decisions, be they related to asset building or debt management, require the capacity to do calculations, including some complex ones. But how numerate are adults, in particular when it comes to calculations related to financial decisions? As the review of studies and surveys that have been implemented in both the United States and in other countries shows, the level of numeracy among the population is very low. Moreover, lack of numeracy is not only widespread but is particularly severe among some demographic groups. This has potential consequences for both individuals and society as a whole because numeracy is found to be linked to many financial decisions. As we shift responsibility from governments and employers onto individuals, it is very important to find ways to equip the new generations with the skills necessary to make savvy financial decisions.

This paper is organized as follows: Section 2 provides an overview of some of the existing work on numeracy as it relates to financial literacy and financial decision-making. Section 3 describes the demographic groups that are most lacking in numeracy. Section 4 reports the relationship between numeracy and financial decision-making. Section 5 provides some discussion and concluding remarks.

\section{Numeracy}

Several data sets from the United States and other countries report information about numeracy and financial decisions, making it possible to examine the link between them. The 2004 U.S. Health and Retirement Study (HRS), a survey that covers people 50 and older, contained questions measuring numeracy. These questions were first used by Lusardi and Mitchell (2007a) to assess the impact of numeracy on financial decision-making. They focused on respondents 51-56 years old (Early Baby Boomers). The questions are as follows:

1) "If the chance of getting a disease is 10 percent, how many people out of 1,000 would be expected to get the disease?"

2) "If 5 people all have the winning number in the lottery and the prize is 2 million dollars, how much will each of them get?"

Respondents who gave the correct answer to either the first or the second question were asked:

3) "Let's say you have 200 dollars in a savings account. The account earns 10 percent interest per year. How much would you have in the account at the end of two years?"

These variables are labeled "Percentage Calculation," "Lottery Division," and "Compound Interest," respectively. Table 1 summarizes how Early Baby 
Table 1

Financial Literacy among Early Baby Boomers

\begin{tabular}{lccc}
\hline \multicolumn{1}{c}{ Question Type } & Correct $(\boldsymbol{\%})$ & Incorrect $(\boldsymbol{\%})$ & Do Not Know $(\boldsymbol{\%})$ \\
\hline Percentage calculation & 83.5 & 13.2 & 2.8 \\
Lottery division & 55.9 & 34.4 & 8.7 \\
Compound interest* & 17.8 & 78.5 & 3.2 \\
\hline
\end{tabular}

Notes: *Conditional on being asked the question. Percentages may not sum to 100 due to a few respondents who refused to answer the questions. Observations weighted using HRS household weights. Adapted from Lusardi and Mitchell (2007a). The number of observations is 1,984.

Boomers answered these questions. Over $80 \%$ got the Percentage Calculation question correct, but only about half could divide $\$ 2$ million by 5 to get the Lottery Division question right. The Interest Compounding question was the most difficult for respondents; only $18 \%$ correctly computed the compound interest. Of those who got that question wrong, $43 \%$ erred by undertaking a simple interest calculation, thereby ignoring the interest accruing on both principal and interest. These three questions, and two additional questions described below, were also asked in the English Longitudinal Study on Aging (ELSA) (see Banks and Oldfield 2007):

4) In a sale, a shop is selling all items at half price. Before the sale, the sofa costs $\$ 300$. How much will it cost on the sale?

5) A second hand car dealer is selling a car for $\$ 6,000$. This is two-thirds of what it cost new. How much did the car cost new?

Respondents in England, as in the United States, show a low level of numeracy: only $11 \%$ of UK respondents are able to answer all five questions correctly. Again, the question about interest compounding is the one that respondents found more challenging. These five questions were also asked of a sub-sample of U.S. sub-prime mortgage borrowers (more on this study below) and very similar findings are seen when looking at this segment of the population: Only $13 \%$ of the sub-prime borrower group were able to answer all five questions correctly (Gerardi, Goette, and Meier 2010). A set of similar numeracy questions was asked in Sweden (Almenberg and Widmark 2011). A similar set of questions (but in different sequences and with some questions asked contingent on previous correct answers) also appeared in the Survey of Health, Retirement and Aging in Europe (SHARE), which surveys a representative sample of the population age 50 and older in 11 countries. The same findings are again reported: Numeracy is low, in this case specifically among the older population, in many European countries (Christelis, Jappelli, and Padula 2010). The countries with the highest 
level of numeracy are Germany, the Netherlands, Sweden, and Switzerland, while the countries with the lowest level of numeracy are Italy and Spain, a finding consistent with the latest data from the OECD's Programme for International Student Assessment (PISA), which measures mathematical and numeracy skills among 15-year-old students.

There is evidence from research in psychology, marketing, and medicine that people are not numerate and have difficulty performing calculations that involve percentages (see Peters et al. 2007, Chen and Rao 2007, and the references therein). These findings confirm evidence from the health literature that patients have difficulty doing simple calculations (Volk 2007).

These are pretty dismal findings, considering the complexities of the calculations involved in many financial decisions. In fact, not just knowledge of interest compounding but even the capacity to do a simple interest rate calculation should not be taken for granted. Lusardi and Mitchell (2011b) designed questions for a special module on financial literacy for the 2004 Health and Retirement Study. The exact question wording is reported below and, given that this is a discussion of numeracy, the first question (designed to measure the capacity to do simple calculations) will be examined in detail:

Suppose you had \$100 in a savings account and the interest rate was $2 \%$ per year. After 5 years, how much do you think you would have in the account if you left the money to grow: more than $\$ 102$, exactly $\$ 102$, less than \$102? Do not know; refuse to answer.

Imagine that the interest rate on your savings account was $1 \%$ per year and inflation was $2 \%$ per year. After 1 year, would you be able to buy more than, exactly the same as, or less than today with the money in this account? Do not know; refuse to answer

Do you think that the following statement is true or false? "Buying a single company stock usually provides a safer return than a stock mutual fund." Do not know; refuse to answer.

Findings from the HRS reveal a low level of numeracy among the older U.S. population: only $67 \%$ of respondents age $50+$ surveyed in this special module picked the correct answer (more than \$102), while one in five picked the incorrect ones (exactly $\$ 102$ or less than $\$ 102$ ). These are particularly worrisome findings because this segment of the population should have already dealt with many financial decisions that required this sort of calculation.

These three questions were thereafter incorporated into several other U.S. national surveys, including the 2007-2008 National Longitudinal Survey of Youth (NLSY), which gathers information on individuals age 23-28 (see Lusardi, 
Mitchell, and Curto 2010, for details). They were also included in the RAND American Life Panel (ALP), covering all ages (Lusardi and Mitchell 2009), and more recently they were added to the 2009 U.S. Financial Capability Study (Lusardi and Mitchell 2011d).

Numeracy is relatively high among the young; $79 \%$ of 23 - to 28 -year-olds in the NLSY can do the $2 \%$ interest calculation correctly. The percentage is much lower, however, when looking at the entire U.S. population, as seen in the most recent data from the 2009 Financial Capability Study. Only 65\% were able to choose the right answer, and as many as $13.5 \%$ indicated that they did not know the answer to this simple question.

These financial literacy questions have been fielded in many other countries, including Germany, the Netherlands, Italy, Sweden, Russia, Japan, and New Zealand. As will be discussed in more detail below, numeracy is seen to be low in many of these countries, as well. ${ }^{3}$ For example, only $40 \%$ of respondents in Italy are able to correctly answer the numeracy question, and as many as $28 \%$ indicated that they did not know the answer (Fornero and Monticone 2011). Results from Japan are similar to those from the United States: about $70 \%$ of respondents are able to answer this question, and $13 \%$ indicated that they did not know the answer (Sekita 2011). Among the countries studied, the highest percentage of correct answers is found in Germany, the Netherlands, and New Zealand where the percentage of correct answers is $82 \%, 85 \%$, and 86\%, respectively (see BucherKoenen and Lusardi 2011; Alessie, Van Rooij, and Lusardi 2011; and Crossan, Feslier, and Hurnard 2011, respectively). These findings are again broadly in line with the mathematics scores reported in the OECD's PISA.

In some countries, the numeracy question was asked in a different way, requiring respondents to perform a more complex calculation related to interest compounding. For example, the question in Sweden's survey was formulated as follows:

Suppose you have 200 SEK in a savings account. The interest is 10 percent per year and is paid into the same account. How much will you have in the account after two years? Respondent calculation (Do not know / Refuse to answer)

The percentage of correct answers changes dramatically with this question format: only 35\% answered correctly, while about half (49\%) gave an incorrect answer (Almenberg and Säve-Söderbergh 2011). We do not know what number respondents came up with, but they may have done a simple interest calculation, as U.S. respondents to the Health and Retirement Study did, not taking into

\footnotetext{
${ }^{3}$ For an overview of the international comparison of financial literacy across eight countries, see Lusardi and Mitchell (2011c).
} 
account that interest compounds on interest. Respondents in Russia were faced with a similar question, worded as follows:

Let's assume that you deposited 100,000 rubles in a bank account for 5 years at $10 \%$ interest rate. The interest will be earned at the end of each year and will be added to the principal. How much money will you have in your account in 5 years if you do not withdraw either the principal or the interest? More than 150,000 rubles / less than 150,000 rubles / I cannot estimate it even roughly.

Even when respondents are presented with a selection of possible answers, as they were here, rather than come up with a number, the proportion of correct answers is very low. In Russia, only $36 \%$ of respondents picked the right answer (more than 150,000 rubles), while 30\% chose an incorrect answer, and 33\% indicated they could not estimate the answer even roughly (Klapper and Panos 2011).

These are important findings because calculations about compound interest serve as the basis of most financial decisions. Most importantly, using credit cards, engaging in a mortgage contract, or fully appreciating the benefits of starting to save early requires some understanding of interest compounding and how it works. Given the prevalence of debt among American families and frequent reliance on high-cost methods of borrowing, it is important to examine how respondents do on questions that are related to debt (Lusardi 2011, Lusardi and Tufano 2009a,b). The question below, taken from the survey from TNS Global, uses yet another format to assess whether individuals have an understanding of interest compounding:

Suppose you owe $\$ 1,000$ on your credit card and the interest rate you are charged is $20 \%$ per year compounded annually. If you didn't pay anything off, at this interest rate, how many years would it take for the amount you owe to double?(i) 2 years; (ii) Less than 5 years; (iii) 5 to 10 years;

(iv) More than 10 years; (v) Do not know;(vi) Prefer not to answer.

Similar to respondents in other countries, when this question was asked of U.S. respondents in 2008, fewer than 36\% answered correctly (Lusardi and Tufano 2009a,b). This is a rather low percentage given how many individuals have credit cards and maintain revolving balances. Moreover, about 20\% indicated that they did not know the answer to this question and as many as $40 \%$ overestimated how long it would take for the debt to double when borrowing at an interest rate of $20 \%$. This tendency to underestimate the power of interest compounding has been shown in other work, as well (Stango and Zinman 2009, Almenberg and Gerdes 2011). 


\section{Who Knows the Least?}

Financial illiteracy and lack of numeracy are not only widespread in the population but are particularly severe in certain demographic groups. Below are some findings about low-numeracy individuals, offered both to pinpoint the groups that are less likely to possess financial knowledge and to discuss what is known about the origins of financial illiteracy.

As discussed in detail in Lusardi and Mitchell (2011b), in the 2004 HRS module on financial literacy, numeracy was found to decline sharply with age. While often not possible to disentangle age from cohort effects, either decline in cognitive ability or low levels of knowledge among older cohorts was notable. Interestingly, this seems to mimic the findings of Agarwal et al. (2009), which show a greater prevalence of financial mistakes among older individuals as well as less advantageous financial offers given to the elderly.

Many countries exhibit large gender differences in financial literacy. Differences between men and women are present not only for older cohorts but also among younger respondents and in the population at large. The data show that women are less likely to answer financial literacy and numeracy questions correctly and also more likely to indicate that they "do not know" the answer to a question. Given this finding, some of the sex differences that we see may result from lack of confidence in financial knowledge rather than lack of actual knowledge. Interestingly, similar differences in financial literacy responses between the sexes are found in countries as different as the United States, Sweden, the Netherlands, Germany Italy, Russia, and New Zealand. In each of these countries, women are disproportionately more likely to indicate that they do not know an answer to a financial literacy question (Lusardi and Mitchell 2011c).

There are large differences in financial knowledge across educational attainment: numeracy, in particular, is especially lacking among those with low educational attainment (Lusardi and Mitchell 2007a,b; Christelis, Jappelli, and Padula 2010). In some data sets, it is possible to correlate measures of financial literacy with measures of cognitive ability, as measured by the Armed Services Vocational Aptitude Battery, which consists of several subtests that measure vocational aptitude in twelve areas (Lusardi, Mitchell, and Curto 2010). While there is a very strong correlation between financial literacy and numeracy and cognitive ability among young respondents in the NLSY, ability hardly explains the many differences that exist in numeracy in the data. In other words, there is a lot of heterogeneity in numeracy, even when examining a narrow age group in the population and when looking at those with similar levels of cognitive ability. There are also large differences among racial and ethnic groups, with African Americans and Hispanics displaying the lowest level of numeracy (Lusardi and Mitchell 2007a,b, 2011d). 
There are other findings that may explain the origins of financial literacy. For example, financial literacy is correlated with family background. Using panel data from the NLSY, Lusardi, Mitchell, and Curto (2010) were able to link financial literacy of 23- to 28-year-olds to certain characteristics of the households they grew up in. They found that even after controlling for many demographic and economic characteristics, respondents' financial literacy is strongly and significantly correlated with the education of their parents (in particular, their mother). In other words, financial literacy may start in the family, perhaps by observing parents' saving and investing habits or by receiving financial education directly from parents (see also Cude et al. 2006; Chiteji and Stafford 1999; Li 2009).

\section{The Impact of Numeracy on Consumer Behavior}

Many papers have documented a strong correlation between financial literacy and a set of behaviors. Bernheim $(1995,1998)$ showed that most households lack basic financial knowledge and cannot perform very simple calculations and that the saving behavior of many households is dominated by crude rules of thumb. Hilgert, Hogarth, and Beverly (2003) found a strong link between financial literacy and day-to-day financial management. Financial literacy has also been linked to a set of behaviors related to saving, wealth, and portfolio choice (for an overview, see Lusardi and Mitchell 2011a). For example, several papers have shown that individuals with greater financial literacy are more likely to participate in financial markets and to invest in stocks (Christelis, Jappelli, and Padula 2010, Almenberg and Widmark 2011, Almenberg and Dreber 2011, Yoong 2011, Van Rooij, Lusardi, and Alessie 2011). Moreover, more literate individuals are more likely to be savvy in choosing mutual funds, including selecting those with lower fees (Hastings and Tejeda-Ashton 2008, Hastings and Mitchell 2011, Hastings Mitchell, and Chyn 2011).

Focusing on numeracy alone, there are several studies documenting its impact on important financial decisions. For example, Lusardi and Mitchell (2011b) show that those who cannot do a 2\% interest rate calculation (i.e., respond with "do not know") are much less likely to plan for retirement and be successful planners (i.e., figure how much they need to save, develop a plan, and stick to a plan). Moreover, those who are not numerate are less likely to accumulate wealth (Lusardi and Mitchell 2011b). Lusardi and Mitchell (2007a) further show that the capacity to do a more complex calculation related to interest compounding is also linked to more retirement planning. This finding is not specific to the United States, but is true in many other countries. For example, in the Netherlands, those who can do a $2 \%$ calculation are much more likely to plan for retirement, and in Italy, those able to do this calculations are more likely to 
participate in private pension plans (Alessie, Van Rooij, and Lusardi 2011, Fornero and Monticone 2011, respectively). Similarly, among Russians, those who demonstrate an understanding of interest compounding are much more likely to participate in pension funds (Klapper and Panos 2011). This is perhaps expected, as questions about retirement planning are related to whether people have calculated how much they need to save for their retirement and, thus, the capacity to do calculations, even rudimentary ones, is important. Numeracy is linked to other financial decisions, as well. For example, Lusardi and Mitchell (2011b) report that those with higher numeracy are much more likely to own stocks. Christelis, Jappelli, and Padula (2010) show that in many European countries, higher numeracy among the older population is associated with owning stocks directly or indirectly via mutual funds and with investment in general, and Almenberg and Widmark (2011) find that numeracy is strongly linked to participation in both the stock and the housing market in Sweden. Most importantly, Gerardi, Goette, and Meier (2010) show not just financial literacy but numerical ability, in particular, is strongly associated with mortgage delinquency and default. Using a rich data set of sub-prime mortgage borrowers, they find that borrowers who display lower numeracy are more likely to have experienced foreclosure or to be behind on their mortgage payments. Lusardi and Tufano (2009a) consider "debt literacy," i.e., the capacity to do calculations relating to household balance sheets and debt problems. They find that those who are more debt literate - who grasp basic concepts relating to debt—are much more likely to pay their credit cards in full, while those who are less numerate are more likely to pay fees or use high-cost methods of borrowing (payday lenders, pawn shops, tax refund loans, auto title loans, and rent-to-own shops). Interestingly, those who demonstrate lack of understanding of interest compounding as well as overestimate the number of years it takes for debt to double when borrowing at very high interest rates are more likely to report having difficulty paying off debt. Similarly findings are reported using data from the UK (Disney and Gathergood, 2011).

\section{Concluding remarks}

Findings from both the United States and other countries regarding the level of numeracy in the adult population give reasons to worry: the level of numeracy is very low and particularly severe among some already vulnerable groups in the population, such as the elderly, women, and those with low educational attainment. This is problematic because numeracy has been found to be linked to financial decision-making, and many governments and employers around the world are increasingly shifting the responsibility for saving, investing, and borrowing onto individuals. Because it is very difficult to improve numeracy 
among the adult population, it is important to improve numeracy and to teach mathematical skills in school and among the young. Such skills can be useful not only in the job market but also in making good financial decisions throughout one's lifetime. The cost of college education has been increasing at a rate faster than inflation, requiring students and their families to be savvy about financial aid and to manage student loans effectively. Not only are young people required to make one of the most important decisions of their lifetime-whether to invest in higher education-during high school, but they are also confronted with numerous decisions of economic consequence: having a car, a cell phone contract, a bank account, and a debit or credit card. Now more than ever, numeracy and financial literacy are lifetime skills that everybody needs to have to be able to live and operate in today's complex economic environment.

\section{References}

Agarwal, S., J. Driscoll, X. Gabaix, and D. Laibson. 2009. The age of reason: Financial decisions over the lifecycle with implications for regulation, Brookings Papers on Economic Activity, Fall 2009, 51-101. http://dx.doi.org/10.1353/eca.0.0067

Alessie, R., M. van Rooij, and A. Lusardi. 2011. Financial literacy and retirement preparation in the Netherlands. Journal of Pension Economics and Finance 10(4): 527-545. http://dx.doi.org/10.1017/S1474747211000461

Almenberg, J., and A. Dreber. 2011. Gender, financial literacy and stock market participation. Working Paper, Stockholm School of Economics.

Almenberg, J., and C. Gerdes. 2011. Exponential growth bias and financial literacy, IZA Discussion Paper n. 5814.

Almenberg, J., and J. Säve-Söderbergh. 2011. Financial literacy and retirement planning in Sweden. Journal of Pension Economics and Finance 10(4): 585-598. http://dx.doi.org/10.1017/S1474747211000497

Almenberg, J., and J. Widmark. 2011. Numeracy, financial literacy and participation in asset markets. Mimeo, Swedish Ministry of Finance.

Banks, J., and Z. Oldfield. 2007. Understanding pensions: Cognitive functions, numerical ability and retirement saving. Fiscal Studies 28(2): 143-170. http://dx.doi.org/10.1111/j.1475-5890.2007.00052.x

Bernheim, D. 1995. Do households appreciate their financial vulnerabilities? An analysis of actions, perceptions, and public policy. In Tax policy and economic growth, 1-30. Washington, DC: American Council for Capital Formation.

- D. 1998. Financial illiteracy, education and retirement saving. In Living with defined contribution pensions, eds. O. Mitchell and S. Schieber, 38-68. Philadelphia, PA: University of Pennsylvania Press.

Bucher-Koenen, T., and A. Lusardi. 2011. Financial literacy and retirement preparation in Germany. Journal of Pension Economics and Finance 10(4): 565-584. http://dx.doi.org/10.1017/S1474747211000485 
Chen, H., and A. Rao. 2007. When two plus two is not equal to four: Errors in processing multiple percentage changes. Journal of Consumer Research 34: 327-340. http://dx.doi.org/10.1086/518531

Christelis, D., T. Jappelli, and M. Padula. 2010. Cognitive abilities and portfolio choice. European Economic Review 54: 18-39. http://dx.doi.org/10.1016/ j.euroecorev.2009.04.001

Chiteji, N., and F. Stafford. 1999. Portfolio choices of parents and their children as young adults: Asset accumulation by African American families. American Economic Review Papers and Proceedings 89: 377-380 http://dx.doi.org/10.1257/aer.89.2.377

Crossan, D., D. Feslier, and R. Hurnard. 2011. Financial literacy and retirement planning in New Zealand. Journal of Pension Economics and Finance 10(4): 619-635. http://dx.doi.org/10.1017/S1474747211000515

Cude, B., F. Lawrence, A. Lyons, K. Metzger, E. LeJeune, L. Marks, and K. Machtmes. 2006. College students and financial literacy: What they know and what we need to learn. Proceedings of the Eastern Family Economics and Resource Management Association, 102-109.

Disney, R., and J. Gathergood. 2011. Financial literacy and indebtedness: New evidence for UK Consumers. Mimeo, University of Nottingham

Fornero, E., and C. Monticone. 2011. Financial literacy and pension plan participation in Italy. Journal of Pension Economics and Finance 10(4): 547-564. http://dx.doi.org/10.1017/S1474747211000473

Gerardi, K., L. Goette, and S. Meier. 2010. Financial literacy and subprime mortgage delinquency: Evidence from a survey matched to administrative data. Federal Reserve Bank of Atlanta Working Paper 2010-10.

Hastings, J., and O. S. Mitchell. 2011. How financial literacy and impatience shape retirement wealth and investment behaviors. NBER Working Paper 16740.

Hastings, J., O. S. Mitchell, and E. Chyn. 2011. Fees, framing, and financial literacy in the choice of pension manager. In Mitchell and Lusardi 2011. 101-115.

Hastings, J., and L. Tejeda-Ashton. 2008. Financial literacy, information, and demand elasticity: Survey and experimental evidence from Mexico. NBER Working Paper 14538.

Hilgert, M., J. Hogarth, and S. Beverly. 2003. Household financial management: The connection between knowledge and behavior. Federal Reserve Bulletin: 309-322.

Klapper, L., and G. Panos. 2011. Financial literacy and retirement planning: the Russian case. Journal of Pension Economics and Finance 10(4): 599-618. http://dx.doi.org/10.1017/S1474747211000503

Li, G. 2009. Information sharing and stock market participation: Evidence from extended families. Mimeo, Federal Reserve Board.

Lusardi, A. 2011. Americans' financial capability. NBER Working Paper 17103.

Lusardi, A., and O. S. Mitchell. 2007a. Baby boomers retirement security: The role of planning, financial literacy and housing wealth. Journal of Monetary Economics 54: 205-224. http://dx.doi.org/10.1016/j.jmoneco.2006.12.001

- 2007b. Financial literacy and retirement preparedness: Evidence and implications for financial education. Business Economics: 35-44. http://dx.doi.org/10.2145/20070104 
. 2009. How ordinary consumers make complex economic decisions: Financial literacy and retirement readiness. NBER Working Paper 15350.

— 2011a. The outlook for financial literacy. In Mitchell and Lusardi 2011, 1-16

. 2011b. Financial literacy and planning: Implications for retirement wellbeing. In Mitchell and Lusardi 2011, 17-39.

-2011c. Financial literacy around the world: an overview. Journal of Pension Economics and Finance 10(4): 497-508. http://dx.doi.org/10.1017/S1474747211000448

. 2011d. Financial literacy and retirement planning in the United States. Journal of Pension Economics and Finance 10(4): 509-525. http://dx.doi.org/10.1017/S147474721100045X

and V. Curto. 2010. Financial literacy among the young. Journal of Consumer Affairs 44 (2): 358-380. http://dx.doi.org/ $10.1111 / \mathrm{j} .1745-6606.2010 .01173 . \mathrm{x}$

Lusardi, A., and P. Tufano. 2009a. Debt literacy, financial experiences, and overindebtedness. NBER Working Paper 14808.

. 2009b. Teach workers about the peril of debt. Harvard Business Review November: $22-24$.

Michell, O.S. and A. Lusardi (eds.). 2011. Financial literacy: Implications for retirement security and the financial marketplace. Oxford, UK: Oxford University Press

Peters, E., J. Hibbard, P. Slovic, and N. Dieckmann. 2007. Numeracy skills and the communication, comprehension, and use of risk-benefit information. Health Affairs 26(2): 741-748. http://dx.doi.org/10.1377/hlthaff.26.3.741

Poterba, J., S. Venti, and D. Wise. 2008. The changing landscape of pensions in the United States. In Overcoming the saving slump: How to increase the effectiveness of financial education and saving programs, ed. Annamaria Lusardi, 17-46. Chicago: University of Chicago Press.

Sekita, S., 2011, Financial literacy and retirement planning in Japan. Journal of Pension Economics and Finance 10(4): 637-656. http://dx.doi.org/10.1017/ $\underline{\mathrm{S} 1474747211000527}$

Stango, V., and J. Zinman. 2009. Exponential growth bias and household finance. Journal of Finance 64: 2807-2849. http://dx.doi.org/10.1111/j.15406261.2009.01518.x

Song, C. 2011. Financial illiteracy and pension contributions: A field experiment on compound interest in China. Mimeo, University of California-Berkeley.

Van Rooij, M., A. Lusardi, and R. Alessie. 2011. Financial literacy and stock market participation, Journal of Financial Economics 101(2): 449-472. http://dx.doi.org/10.1016/j.jfineco.2011.03.006

Volk, R. 2007. Clarifying Values: Non-Numerical Approaches for Low Literacy Patients. Presentation to the 2007 Summer Institute on Informed Patient Choice, Center for the Evaluative Clinical Sciences. Hanover, NH: Dartmouth College.

Yoong, J. 2011. Financial illiteracy and stock market participation: Evidence from the RAND American Life Panel. In Mitchell and Lusardi 2011, 76-100 